compensate for the stress of living in a poor environment; and recreational facilities are not as accessible for people with no transport or who have small children. ${ }^{17}$ These factors might need to be modified first if the promotion of healthier lifestyles is to be successful.

The new contract requires general practitioners to provide checks every three years for patients aged 1674 years. It is thus of some concern that our findings reinforce those of other studies suggesting that unselective health checks might be an inefficient use of valuable resources and might promote further inequalities in health. Despite their simplicity and economic attractiveness health checks may have only a limited part to play in any comprehensive plan for health promotion as they cater primarily for the fitter and better motivated members of the public. The global strategy required to combat ischaemic heart disease must incorporate political will, in the form of public education and strong price and advertising controls to reduce the consumption of saturated fats and tobacco, as well as enthusiasm, organisation, and vigilance by primary health care teams. The medical profession should not be cajoled into accepting complete responsibility for health promotion and the prevention of ischaemic heart disease, so absolving the government of its obligations.

We thank the patients and staff of the Berinsfield Health Centre and the staff and resources of the Oxford community health project and the University of Oxford Department of Community Medicine and General Practice. Our study was supported by a grant from the Scientific Foundation Board of the Royal College of General Practitioners. DM, LJ, and AF are supported by the Imperial Cancer Research Fund. The Unit of Clinical Epidemiology is funded by the Department of Health and by Oxford Regional Health Authority.

1 Secretaries of State for Social Services, Wales, Northern Ireland, and Scotland Promoting better health. London: HMSO, 1987. (Cmnd 249.)

2 Department of Health. General practice in the National Health Service: the 1990 contract. London: Department of Health, 1989.

3 Hart J T. The inverse care law. Lancet 1971;i:405-12. Pr, Juality? I R Coll Gen Pract 1989;39:196-9.
or

5 Pill R, French J, Harding K, Stott NCH. Invitation to attend a health check in a general practice setting: comparison of attenders and non-attenders. $\mathcal{F} R$ Coll Gen Pract 1988;38:53-6.

6 Fullard EM, Fowler GJ, Gray JAM. Facilitating prevention in primary care. BrMed f 1984;289:1585-7.

7 Fullard EM, Fowler GH, Gray JAM. Promoting prevention in primary care: controlled trial of low technology low cost approach. Br Med $\mathcal{J} 1987$ 294: $1080-2$.

8 Sacks G, Marsden R. Evaluation of a practice-based programme of health checks: financial cost and success at risk detection. $f R$ Coll Gen Pract 1989;39:369-72.

9 Pill R, Stott N. Invitation to attend a health check in a general practice setting: the views of a cohort of non-attenders. $\mathcal{F} R$ Coll Gen Pract 1988;38:57-60.

$10 \mathrm{Vijay} \mathrm{N}$. Investigation of non-responders at a cervical cancer screening clinic in Manchester. BrMed F 1988;296:1041-2.

11 Coulter A, Baldwin A. Survey of population coverage in cervical cancer screening in the Oxford region. $f R$ Coll Gen Pract 1987;37:441-3.

12 Wrench J. Irvine $R$. Coronary heart disease: account of a preventative clinic in rench J, Irvine R. Coronary heart disease: account of
general practice. $\mathcal{F}$ R Coll Gen Pract 1984;34:477-81.

13 French K, Porter ADM, Rolinson SE, McCallum FM, Howie JGR, Roberts MM. Attendance at a breast screening clinic: a problem of administration or attitudes? $\mathrm{Br}$ Med $\mathcal{F}$ 1982;285:617-20

14 Smail SA. Opportunities for prevention: the consultation. $\mathrm{Br} \mathrm{Med} \mathcal{f} 1982$ 284: 1092-3.

15 Marsh GN, Channing DM. Narrowing of the health gap between a deprived and an endowed community. Br Med F 1988;296:173-6.

16 Townsend P, Davidson N. Inequalities in health: the Black report. London: Penguin, 1982.

17 Coulter A. Lifestyles and social class: implications for primary care. $\mathcal{J} R \mathrm{Coll}$ Gen Pract 1987:37:533-6.

(Accepted 6 February 1990)

\title{
Screening in Practice
}

\section{Maternal and fetal screening for antenatal care}

\author{
M J V Bull
}

The chief aim of antenatal care is to maintain and improve the health of both mother and fetus during pregnancy so that they are in optimum condition when parturition occurs. Subsidiary objectives are the early diagnosis of variations from the norm and the detection of asymptomatic, potentially threatening conditions that may arise. Screening is, in fact, a term that broadly covers this process of detection and for many years it has been accepted as an integral part of good maternity care. The procedures used were at first mainly directed at preserving the wellbeing of the mother but, particularly during the last two decades, innovative techniques have been introduced that enable indirect but sophisticated monitoring of the fetus.

\section{Screening before conception}

Preparation for pregnancy can sometimes be combined with the provision of contraceptive advice. For example, rubella state should be determined, and if the woman is not immune she can be immunised before contraception is abandoned. Many women are increasingly concerned about other infective hazards to the fetus, such as toxoplasmosis, so a comprehensive serum TORCH screen (toxoplasmosis, rubella, cytomegalovirus, herpes virus) may be appropriate, at least from the viewpoint that a mother shown to be immune to these conditions can be reassured that reinfection during pregnancy is unlikely. At the same time the woman's $\mathrm{ABO}$ blood group and rhesus factor should be determined (if they are not already known) to warn of the possibility of isoimmunisation during pregnancy. Similarly, haemoglobinopathies should be looked for-for example, sickle trait in Afro-Caribbean women and thalassaemia in those of Mediterranean or Asian origin.

A family history should also be obtained regarding possible genetic anomalies, and if any are present formal genetic counselling should be arranged before conception occurs. This is especially necessary where there is a history of X-linked or autosomal defects, chromosomal rearrangement, or any major developmental abnormality. A considerable advance in preconceptual counselling has been the development of a technique for gene tracking in prospective parents and their families. It uses DNA probes and markers and allows assessment for the risk of such conditions as Huntington's chorea, cystic fibrosis, muscular dystrophy (Becker, Duchenne, or myotonic), neurofibromatosis, and familial polyposis coli as well as haemophilia $\mathrm{A}$ and $\mathrm{B}$ and the haemoglobinopathies. Guidelines on multistage screening and tests for carrier states were published in 1987 in the King's Fund consensus statement on screening for fetal and genetic abnormality.'

\section{Screening during pregnancy}

Screening procedures during pregnancy can conveniently be associated with the key points during antenatal care when the mother would be seen by her doctor $^{2}$ rather than by her midwife. These are at 


\begin{tabular}{|c|c|c|c|c|c|c|}
\hline & Urine & Blood & $\begin{array}{c}\text { Chorionic } \\
\text { villus sampling }\end{array}$ & $\begin{array}{l}\text { Amniotic } \\
\text { fluid }\end{array}$ & Ultrasonography & $\begin{array}{l}\text { Vaginal } \\
\text { swabs }\end{array}$ \\
\hline Preconception & $\begin{array}{l}\text { Diabetes } \\
\text { Nephropathy }\end{array}$ & $\begin{array}{l}\text { Rh state } \\
\text { Rubella state } \\
\text { Haemoglobinopathy } \\
\text { Carrier states }\end{array}$ & & & & \\
\hline $8-10$ weeks & Bacteriuria & $\begin{array}{l}\text { Syphilis } \\
\text { Hepatitis (HBsAg) }\end{array}$ & $\begin{array}{l}\text { Karyotype } \\
\text { Gene defects }\end{array}$ & & & \\
\hline 16-18 weeks & & $\begin{array}{l}\text { Anaemia } \\
\text { Rh or ABO antibodies } \\
\alpha \text { Fetoprotein }\end{array}$ & & $\begin{array}{l}\text { Karyotype } \\
\alpha \text { Fetoprotein } \\
\text { Acetylcholin- } \\
\quad \text { esterase }\end{array}$ & $\begin{array}{l}\text { Multiple pregnancy } \\
\text { Gestational age } \\
\text { Macrosomal defects }\end{array}$ & \\
\hline 28-30 weeks & & $\begin{array}{l}\text { Anaemia } \\
\text { Rh or ABO antibodies } \\
\text { Gestational diabetes }\end{array}$ & & $\begin{array}{l}\text { Haemolytic } \\
\text { disease }\end{array}$ & $\begin{array}{l}\text { Intrauterine growth } \\
\text { retardation } \\
\text { Placental site }\end{array}$ & \\
\hline 34-36 weeks & $\begin{array}{l}\text { Pre-eclamptic } \\
\text { toxaemia }\end{array}$ & $\begin{array}{l}\text { Anaemia } \\
\text { Rh or ABO antibodies } \\
\text { Pre-eclamptic toxaemia }\end{array}$ & & $\begin{array}{l}\text { Haemolytic } \\
\text { disease }\end{array}$ & $\begin{array}{l}\text { Intrauterine growth } \\
\text { retardation }\end{array}$ & $\begin{array}{l}\text { Herpes simplex } \\
\quad \text { virus } \\
\text { Group B } \\
\text { streptococcus }\end{array}$ \\
\hline
\end{tabular}

booking (8-10 weeks), at 16-18 weeks, at 28-30 weeks, and at 34-36 weeks of gestation. The range of tests by gestational stage is summarised in the box.

\section{At $8-10$ weeks}

This is the time when most women present for confirmation of pregnancy. If preconceptual screening has not been undertaken the appropriate investigations and counselling should be carried out.

A urine sample should be tested to exclude diabetes or nephropathy, and if pregnancy is not clinically certain this sample can be used for a pregnancy test. A clean catch sample should also be examined to exclude asymptomatic bacteriuria.

Blood samples should be taken for full blood count, electrophoresis (in appropriate ethnic groups), $\mathrm{ABO}$ and rhesus grouping, determination of rubella state (if not already known), testing for toxoplasma if requested, and serology for syphilis. Screening for hepatitis B carrier state ( $\mathrm{HBsAg})$ is already routine in some areas and seems justifiable as early passive-active immunisation of babies born to seropositive mothers has been shown to be effective. ${ }^{3}$ It seems likely that HIV state will also be a mandatory screen in future.

Chorionic villus sampling should be offered to any women aged over 35 and those who have experienced a previous pregnancy with chromosomal abnormality or are known to have a single gene disorder for which the pregnancy is at high risk and which can be detected prenatally. Amniocentesis at a later stage (16 weeks) may, however, be preferable as it is believed to carry a lower risk of miscarriage and has the advantage that screening for neural tube defect can be done at the same time. Genetic defects can be detected more rapidly with chorionic villus sampling, however, and should termination of pregnancy be an option it can be undertaken with less distress to the patient if performed before the end of the first trimester.

\section{At 16-18 weeks}

Blood should be sent for determination of $\alpha$ fetoprotein concentrations to screen for neural tube defect. Gestational age should be confirmed by ultrasonography and women with $\alpha$ fetoprotein concentrations more than 2.5 times the mean for gestational age should be offered a high resolution ultrasound scan; if this is indeterminate they should be offered amniocentesis.
An ultrasound scan should be arranged routinely to exclude multiple pregnancy, confirm gestational age, and define the site of the placenta. If there is a history of previous macrosomal defects (cardiac or renal tract disorders, limb reduction defects, osteogenesis imperfecta, etc) a high resolution anomaly scan should be done at 18-20 weeks' gestation.

Amniocentesis should be offered to women over 35 or with a history of chromosome or gene defects who have not been screened by chorionic villus sampling or who have raised serum $\alpha$ fetoprotein concentrations. A raised $\alpha$ fetoprotein concentration in amniotic fluid may be disregarded if there is no concomitant rise in acetylcholinesterase activity and if an anomaly scan is normal. A low serum $\alpha$ fetoprotein concentration may be associated with Down's syndrome, particularly in older women,${ }^{4}$ and if this is found then karyotyping of fetal cells from the liquor amnii is also indicated.

\section{At 28-30 weeks}

This assessment is to provide a baseline for the third trimester. Developmental anomalies are unlikely now but patients should be screened for such conditions as gestational diabetes, $\mathrm{ABO}$ and $\mathrm{Rh}$ isoimmunisation of the mother, the development of pre-eclampsia, and growth retardation in the fetus.

Blood should be taken for a full blood count, to exclude iron deficiency or macrocytic anaemia. In $\mathrm{Rh}$ negative women the blood group should be checked and isoimmunisation excluded. If anti-D antibodies are detected the test should be repeated within two weeks. If a rising titre is found amniocentesis may be indicated to confirm haemolytic disease and to assist in decisions regarding the timing of the delivery. A random plasma glucose concentration should be estimated in obese patients and women who have previously had very large babies or who have had glycosuria. This should preferably be done more than two hours after the last meal. ${ }^{5}$ If glucose concentration is found to be raised $(>5 \mathrm{mmol} / \mathrm{l})$ a fasting sample should be checked, and if it is still abnormal a formal glucose tolerance test should be performed.

Ultrasound examination should be performed if at the previous examination at $16-18$ weeks the placenta had been encroaching on the lower segment of the uterus; as the uterus enlarges the placenta is usually drawn up away from the cervix but it is important to establish that no degree of praevia persists. If the fetus seems clinically to be small for gestational age then growth 
parameters should be established and a further scan arranged three or four weeks later to check that fetal growth is not retarded.

\section{At 34-36 weeks}

Urine testing is routine at every antenatal examination, but as the pregnancy approaches term proteinuria is more likely to signify pre-eclampsia, so other causes such as contamination of the sample with vaginal secretion or a urinary tract infection must be positively identified. This is done with a carefully collected midstream specimen that is examined microscopically and sent for culture.

Blood is again checked at this visit for evidence of iron deficiency or other anaemias. The blood group should be checked and $\mathrm{ABO}$ or rhesus antibodies sought. If there are symptoms or signs of pre-eclampsia then raised concentrations of plasma urea and urate, and activity of aspartate aminotransferase provide confirmation and have prognostic value.

Ultrasound examination is again indicated if there is clinical evidence of fetal growth retardation or if, in the very obese patient, there is doubt regarding the presentation of the fetus.

Radiological examination (a single lateral view of the pelvis taken with the patient standing) is advisable in nulliparous patients when the fetus is in breech presentation. This allows the true conjugate measurement of the pelvic brim to be obtained, which together with the shape of the sacral curve may influence decisions regarding the appropriate method of delivery .

Vaginal swabs should be taken at this point $(a)$ if the woman complains of symptoms suggesting candidiasis or other genital infection - after a pathogen has been identified appropriate treatment should be given before the onset of labour; the hazard to the fetus in the birth canal can thus be reduced; $(b)$ if primary herpes genitalis has occurred during the pregnancy, swabs in virus medium should be sent for culture (management of this situation is somewhat contentious, ${ }^{6}$ so if swabs prove positive the advice of a virologist should be sought); (c) if a group B streptococcus has previously been cultured from the vagina. If the result is still positive (as it may be in up to $15 \%$ of women) the neonate should be observed with special attention in the first few days of life and itself be screened for bacteria and given prompt chemotherapy in the event of positive culture or fever (streptococcal septicaemia causes perinatal death in about two babies per 1000, an avoidable tragedy).

\section{Conclusion}

Advances in molecular biology, immunology, and genetics have now enabled more than one hundred biochemical defects to be identified, either in the prospective parents as carriers or in an affected fetus. Perhaps the most exciting development is the possibility of screening for cystic fibrosis $:$ one in 20 of the white population carries the newly identified defective gene; the incidence of this distressing and potentially fatal condition is approximately one in 2000 live births. Now that the means is available, the ethics and logistics of carrier screening in reproductive populations for this and similarly identifiable recessive conditions will need to be considered.

I thank Professor Sir Alexander Turnbull, Dr Pau Chamberlain, and Dr Helen Frith for advice during the preparation of this article

1 King's Fund Forum. Consensus statement: screening for fetal and genetic abnormality Br Med 7 1987:295:1551-3.

Bull M JV. A problem orientated approach to antenatal care. Medicine in Practice $1984: 2$ (No 31$): 10-23$

3 Mazel JA, Schalm SW, de Gast BC, et al. Passive-active immunisation of neonates of $\mathrm{HBsAg}$ positive carrier mothers: preliminary observations. Br.Hed f 1984:288:513-6.

+ Cuckle HS, W'ald NJ, Thompson SG. Estimating a woman's risk of having a pregnancy associated with Down's syndrome using her age and scrum alph fetoprotein level. Br f Obstet Gynaecol 1987;94:387-402.

5 Lind $T$. Antenatal screening for diabetes mellitus. Br $\mathcal{J}$ Obstet Gynaecol 1984;91:833-4.

6 Kelly f. Genital herpes during pregnancy: routine virological screening is futile. Br Med F 1988;297:1146-7.

Anonymous. Neonatal infection with group B streptococci [Editorial]. Lancel $1981 ;$ ii: $181 \cdot 2$

8 Anonvmous. Cystic fibrosis: prospects for screening and therapy [Editorial] ancet 1990):335:79-80.

\section{BOOKS RECEIVED}

\section{Pharmacology \\ C.MR Workshop Series. "International Medicines Regulations: a Forward Look to 1992." [Workshop, London 20/21 September 1988.] Ed S R Walker, J P Griffin. Pp xiv + 312; figs f55.) Dordrecht: Kluwer Academic, ISBN 0-7462-0120-6.}

\section{Psychiatry}

The Library of Analytical Psychology. "Psychopathology: Contemporary Jungian Perspectives." Ed A Samuels. Jungian Perspectives." Ed A Samuels. Peterson el al. (Pp xii $+355 ; \& 14.95$ Peterson et al. (Pp xii +355; 114.95 paperback.) London:

The Oedipus Complex Today: Climical Implications. R Britton, $M$ Feldman. E O'Shaughnessy. $\quad P p$ viii $+152 ; £ 7$ paperback.) London: Karnac, 1989 ISBN 0-946439-55-9.

\section{Psychology}

On Becoming a Psychotherapist. Ed W Dryden, L Spurling. (Pp $x+2+8$ E12.95 paperback London: TavisI12.95 paperback.' London: Tavistock Routec

The Practice of Behavioural Medicine. Ed S Pearce, J Wardle. (Pp xvii +313 £35.) Oxford: British Psychological Society in association with Oxford University Press, 1989. ISBN 0-19 261691-9.
Studies in Bivethics. "The Values of Psychotherapy "J Holmes, R Lindley. Preneral editor P Singer. Pp ix +256; General editor Pinger. Pp ix +256 17.50. Oxford: Oxford Unicer

\section{Radiology}

Medical Science Series. "The Physic and Radiobiology of Fast Neutron Beams." D K Bewley. Series editor RF Mould. Ppxii + 179; figs; $£ 29.50$ Bristol: Hilger, 1989. ISBN 0-85274- Surgery

Orthopaedic Radiologv: Pantem Recognition and Differential Diagnosis. Renton. (Pp viii +384 ; figs; $\{49.95$. London: Dunitz, 1990. ISBN 0-948269-58-8.

\section{Rheumatology}

Pocket Consultant. "Rheumatolog:." G V Campion, A St J Dixon. Pp vi 314; figs; $£ 13.95$ paperback.) Oxford Blackwell Scientific, 1989. ISBN $0-632-01112-2$

Sociology

Readings in Medical Socology. Ed S Cunningham-Burler. N P M Keganer. Pp $x \cdot 261$; figs; $\{10.95$ paperback. I. London: Tavistock Rou ledge, 1990. ISBN 0-415-00833-6.

Statistics

Monographs in Epidemiologv and Biostatstics. Col 12. "Statistical Methor in Epidemiology." H A Kahn, C T Sempos. Pp xiii - 292: figs; $£ 19.50$ paperback New York: Oxford Unicersity Press, 1989, ISBN 0-19. 505049.5

Statistical Methods for Medical Investigations. B S Everitt. (Pp ix + 195; figs; f25. New York: Oxford University Press, 1989. Distributed by Edward Arnold. ISBN 0-85264-312-8

Color Atlas of Operatice Techmques in Head and Neck Surgerv: Mouth. Pharinx, Larynx, Thyroid, Parotid. Soft Tissues and Reconstructive Surgerv. Vol 2. PJ Shah. (Pp 312; colour plates; £110.) London: W'olfe Medical Publiations, 1989. ISBN 0-7234-1508-0.

Hanual of Surgical Clearance. Ed A E Morevra, J B Kostis. Pp vii 133; paperback, price not stated., St Louis: Ishivaku EuroAmerican Inc., 198 ISBN 0-912791-47-0.

\section{Surgery - transplantation}

Organ Transplantation: Current Cilmical and Immunological Concepts. Ed I Brent, R A Sells. Pp xiv +299 ; figs £35. London: Baillière Tindall 1989. Distributed by Harcourt Brace Jovanovich. ISBN 0-7020-1393-5.

Terminal care

Give Sorrow Words: Working With a l)ing (hild. D) Judd. Pp xxii +218 figs; £11.95 paperback. London: Free Association Books, 1989. ISBN 185343-098-6.

\section{Toxicology}

Year Book of Toxicology 1989. E Sunshine. (Pp xii; $\{35.50$., Boca Raton: CRC Press, 1989. Distributed by CRC Press, 1989. Distributed by 3301-1.

\section{Vascular surgery}

Endovascular Surger:. W S Moore, S Ahn. Pp xx +550 ; figs; f64.) Philadelphia: Saunders, 1989. Distributed by Harcourt Brace Jovanovich. ISBN 0-7216-6532-2

\section{Virology}

Developments in .11olecular l'irolog. "Molecular Biology of Iridoviruses. Ed G Darai. Series editor Y Becker. Pp xiii + 305; figs; f79.95.) Boston: Kluwer Academic, 1989. ISBN 0-7923-0506-X.

\section{Miscellaneous}

Chatto CounterBlasts. No 9. "Mr Bevan's Dream: Why Britain Needs Its Welfare State." S Townsend. PF 74: 22.99 paperback.) London: Chatto and Windus, 1989. ISBN Chatto and

The Complete Begimner's (iuide to the lare Portiolio. B Thomas, A Thomas.
(Pp xiv $+310 ;+$ index; figs; $\mathfrak{1} 14.95$ paperback. 1989. Available from Thomas Technical Publications l.imited, Copestake Cottaye, Pinfold Lane, Bradley, Ashbourne, Derohire DE6 IPN ISBN 1-871915-05-8. 1 Doctor's Life in Britain and famaica. $\mathrm{H} D$ Chambers. $\mathrm{P}_{\mathrm{P}}$ ix +52 ; figs; E5 paperback.) Edinburgh: Pentland Press, 1989. ISBN 0-946270-75-9.

Electricity, Saferv, and the Patient. J M R Bruner, P F Leconard. $\mathrm{Pp}$ $\mathrm{x}+338$; figs; $\$ 67$. Chicago: Year Book Medical Publishers., 1989. Distr huted by. Wolfe Medical Publications. ISBN 0-8151-1291-2.

Injury Prevention: Meeting the Chatenge. National Committee for Injury Prevention and Control. $(\mathrm{Pp} \mathrm{xv}+303$ figs; $\{35$. New York: Oxford Univesitv Press, 1989. ISBN 0-19-5062-48-5. More of Mould's Medical Anecdote RFMould (Ppxi+269: figs: 514.95 . Bristol: Hilger, 1989. ISBN 0.85274 $119-7$

Protection for Life: How to Boost Your Body's Defences Against Free Radicals and the Ageing Effects of P'ollution and Modern Life Stvles. Y Niwa, II Hansen $P$ p 80; figs: fl 99 paperback Wellinghorous. Thoper1989. ISBN 0-7225-2197-9.

Supporting the Johless: Dectors, Clergy, Police, Probation Offuers. S Fineman. Pp ix +194; $£ 10.95$ paperback. London: Tavistock/Routledge, 1990 ISBN 0-415-01765-3. 